\title{
ACCELERATE NON-ENGLISH LECTURERS' MASTERY OF ENGLISH THROUGH CONTENT-BASED INSTRUCTION
}

\author{
Asna Usman Dilo \\ IAIN Sultan Amai Gorontalo \\ email: asnadilo77@gmail.com \\ Sri Dewi Jayanti Biahimo \\ IAIN Sultan Amai Gorontalo \\ email:dewi_gorontalo@yahoo.com
}

\begin{abstract}
The articles aims of discussing about using content based approach in accelerating non-English lecturers' mastery of English. Out of three main types of Content-Based Instruction, this study uses the theme-based language instruction to accelerate the non-English lecturers' mastery of English. Therefore, the question was asked; can the content based approach accelerate the non-English lecturers' mastery of English. This study was an action research study, where pre-test and posttest were administered to obtain the data, in addition to observation and literature study. The study is conducted in two cycles; each cycle consists of 5 meetings. The indicator of the study is that the study is completed when $75 \%$ of the lecturers were able to reach at least 75 points in the test. The pretest reveals that the average lecturers' score is 63.50 and following the treatment using this approach at the end of the second cycle, the average lecturers' mastery is $80.2 \%$. Therefore, it is concluded that content-based instruction can accelerate the non-English lecturers' mastery of English.
\end{abstract}

KEYWORDS: Content-Based Instruction, English Mastery, Non-English Lecturers

\section{A. INTRODUCTION}

ontent-based instruction (henceforth will be called as CBI) is one of approaches in
teaching language as part of the communication process. There are various definitions
of CBI has many definitions proposed by various scholars such as: Brinton, Snow, and Wesche (2003 as cited in Ameri and Fatemi, 2014) who defined it as a way of teaching that merge language teaching objectives with certain content. This definition is also resounded in Leaver and Stryker (1989 as cited in Amiri and Fatemi, 2014) who write that CBI is an instructional approach where language competencies are achieved through changing the focus of learning the language to learning the topic. It focuses on the usage of the language rather than the talking about the language (Saeidi and Farshchi, 2015).

Content-based instruction was intended to provide students with increased motivation in subject matter as well as opportunities to experience larger discourse-level features and social interaction patterns essential to language use (Lee, Quinn and Valdes (2013). This also argued by Donna M Brinton (2012), she said CBI prepares students to more complex challenges of language learning in real world, and to engage students in meaningful and broader ways of learning the language to be able to transfer the language skills and content to real life. CBI can increase learners' critical thinking and leads them to learning the language faster and more 


\section{Volume 5, Number 02, December 2019}

enjoyably, in addition to improvement of cognitive and academic achievements in language proficiency (Stroller, 2002; Kessler and Quinn, 1987).

English mastery is as the aim of teaching English as foreign language (TEFL) encourage both lecturers and students to be able to use English in every of their activities, either in academic or non-academic activities. The necessity of English mastery is caused by the globalization. It has brought changes in education which the demand of qualified lecturers and students are increasing. One of the indicators of qualified lecturers is mastering any foreign languages, mainly English. In Indonesia, lecturers are expected to perform their best in three main area, teaching and learning, research, and community outreach. In order to do these, in addition to their own core competencies, lecturers are expected to have at least good command in English.

As most of these up to date academic references are now written in English, English mastery becomes even more necessary. There are various courses available for lecturers; however, finding time amidst their busy teaching schedule is an issue. Also, some have experienced that English courses do not significantly lasting influence on their skill improvement of this language. Many of the available courses are not tailored to their needs or that they cannot choose what they wanted to learn in the span of a course cycle.

It is a common phenomenon for lecturers, especially those with non-English background, to for instance, ask for translation services to translate their journals in order to be published in internationally accredited journals and publishers. There is nothing wrong with this; however, it is often found that not all translation services are able to translate the intended purpose of the original author into the target language. Even, some lecturers have become prey to the predatory journals.

However, the researchers have been investigated the implementation CBI approach in teaching English, but the focus of this research was different. This research focused on the participant of non-English lecturers in Islamic higher education. It was investigated non-English lecturers competence in mastering English.

Therefore, the research question was formulated in; can content based instruction accelerate the non-English lecturers' mastery in English. The objective of research was described the acceleration of non-English lecturers' mastery in English when the content based instruction was implemented. 


\section{B. REVIEW OF LITERATURE}

$\mathrm{CBI}$ is common approach in teaching and learning language, especially English teaching. Hedyan Putra and Lenny Marzulina (2014) investigated the content based instruction to improve students' reading comprehension. They identified that the approach can improve the students' reading comprehension, after applying the approach in classroom action research. Windhy Eka Nuraini (2017) observed the implementation of CBI approach in teaching English at elementary school. She found that CBI approach is interested either for teacher or students. Because, she used qualitative descriptive, thus she described the implementation of CBI approach in the classroom, such as how many percentage of teacher's talk which delivered in English. She also found that the students were easy to understand the lesson, because the teacher used Content Based Instruction (CBI).

Content-based instruction (henceforth will be called as CBI) is one of approaches in teaching language as part of the communication process. There are various definitions of CBI has many definitions proposed by various scholars such as: Brinton, Snow, and Wesche (2003 as cited in Ameri and Fatemi, 2014) who defined it as a way of teaching that merge language teaching objectives with certain content. This definition is also resounded in Leaver and Stryker (1989 as cited in Amiri and Fatemi, 2014) who write that CBI is an instructional approach where language competencies are achieved through changing the focus of learning the language to learning the topic. It focuses on the usage of the language rather than the talking about the language (Saeidi and Farshchi, 2015).

Content-based instruction was intended to provide students with increased motivation in subject matter as well as opportunities to experience larger discourse-level features and social interaction patterns essential to language use (Lee, Quinn and Valdes (2013). This also argued by Donna M Brinton (2012), she said CBI prepares students to more complex challenges of language learning in real world, and to engage students in meaningful and broader ways of learning the language to be able to transfer the language skills and content to real life. CBI can increase learners' critical thinking and leads them to learning the language faster and more enjoyably, in addition to improvement of cognitive and academic achievements in language proficiency (Stroller, 2002; Kessler and Quinn, 1987).

\section{METHOD}

This study is a classroom action research (CAR) as it serves the purpose of the study to accelerate the mastery of non-English lecturers' mastery in English. Bogdan \& Biklen (1992, as cited in Khasinah, 2013) explain that action research is a systematic collection of information 


\section{Volume 5, Number 02, December 2019}

that is designed to bring about social change. This study is conducted at IAIN Sultan Amai Gorontalo from February-April 2018. The subject of this study is 10 lecturers at the Faculty of Education Science and Teaching who voluntarily participate in the study

The data in this study are collected using pre-test and post-test with The Nelson Test of Achievement Form $050 \mathrm{C}$ as its instrument adapted from Amiri and Fatemi (2014). This test was developed by Fowler and Coe back in 1976 and has been widely used to test general proficiency in English. Additional data are also collected using observation and documents study.

The research is conducted in two cycles, where each cycle consists of 5 meetings. Research subjects were asked to discuss, read, and present topics related to the themes of each cycles. At end of each cycle, lecturers' achievement is measured using the test. The indicator in this study is that the research will only be completed when $75 \%$ of the participants have reached the score of at least 75 in this Nelson Test.

\section{FINDINGS AND DISCUSSION}

\section{FINDINGS}

As this study is conducted at the faculty of education sciences whose lecturers are mostly holds master degree in education sciences and within the Islamic university. The theme of these two cycles revolve around education and Islamic world. The is listed in Table 1 below

Table 1. Theme discussed in two cycles of research

\begin{tabular}{|l|l|}
\hline Cycle 1 & Education in Islamic World \\
\hline Cycle 2 & Leadership in Islamic world \\
\hline
\end{tabular}

In each of these theme, the participants are presented with several topics regarding to the theme. And then they discussed and present their ideas the related theme.

\section{Preliminary Study}

The Nelson Test of Achievement form $050 \mathrm{c}$ is used in this study. This test is used as its reliability and validity have been tested and due to the time limitation on this study the researchers have no time to develop a test on their own. Hence, a readymade test is used. The results of the pre-test is presented in Table 2 below.

Table 2. Preliminary test result

\begin{tabular}{|l|l|}
\hline \multicolumn{1}{|c|}{ Lecturer's ID } & Score \\
\hline L1 & 66 \\
\hline L2 & 64 \\
\hline L3 & 64 \\
\hline
\end{tabular}




\begin{tabular}{|l|l|}
\hline L4 & 70 \\
\hline L5 & 66 \\
\hline L6 & 52 \\
\hline L7 & 67 \\
\hline L8 & 60 \\
\hline L9 & 66 \\
\hline L10 & 60 \\
\hline Average & 63.5 \\
\hline
\end{tabular}

Out of 10 lecturers only one lecturer who got 70 score, one lecturer who got 50 score and the rest range around 60.

\section{The first cycle.}

In this first cycle, the participants are presented with one article related to the topic on education in Islamic world. They read it out loud, they discuss the idea of education in Islamic university and Islamic world in general during discussion session. In each meeting, two participants present their ideas of education in Islamic world, what they thought of Islamic education, what are lacking in Islamic education in Indonesia and in their own institution.

At the end of the first cycle the test is readministered with the number being scrambled and the result is presented in table 3 below.

Table 3. First-cycle test result

\begin{tabular}{|l|l|}
\hline \multicolumn{1}{|c|}{ Lecturer's ID } & Score \\
\hline L1 & 70 \\
\hline L2 & 68 \\
\hline L3 & 68 \\
\hline L4 & 76 \\
\hline L5 & 72 \\
\hline L6 & 68 \\
\hline L7 & 70 \\
\hline L8 & 74 \\
\hline L9 & 70 \\
\hline
\end{tabular}




\begin{tabular}{|l|l|}
\hline L10 & 66 \\
\hline Average & 70.2 \\
\hline
\end{tabular}

Regardless to this slight improvement, as shown in the average score above. This result is yet to meet the standard achievement set as the indicator of this study. Therefore, this study is carried out to the next cycle with slight improvement in the preparation stage, where participants are given time in advance to read the materials regarding the theme of Leadership in Islamic world.

\section{Cycle II}

As it has been mentioned above that during the preparation stage, the materials for the Leadership in Islamic world are given in advance for the participants to read and understand the text. During the meeting, participants were given time to asks questions on the world that may not familiar to them. In addition, they also prepare similar materials on other leader figures in Islamic world. Each of the participant present their own figure at the end of the meeting. Following the presentation of the leader figure, participants write down their review of the leader and discusses it with the class. At the end of the cycle, the participants were given a posttest from the Nelson test of achievement. The result is presented in the following Table 4

Table 4. Participants' test result at the end of cycle II

\begin{tabular}{|l|l|}
\hline \multicolumn{1}{|c|}{ Lecturer's ID } & Score \\
\hline L1 & 78 \\
\hline L2 & 84 \\
\hline L3 & 82 \\
\hline L4 & 88 \\
\hline L5 & 82 \\
\hline L6 & 74 \\
\hline L7 & 78 \\
\hline L8 & 80 \\
\hline L9 & 78 \\
\hline L10 & 80 \\
\hline Average & 80.2 \\
\hline
\end{tabular}


As it is seen in the table above, the average score has reached 80.2. Considering that the indicator for the completion of this study is that $75 \%$ of the participants have reached the score of at least 75 , then this study is concluded.

\section{Discussion}

As seen in the findings above, the theme-based instruction is able to increase the participants' knowledge from the average of 63.5 to 80.2 at the end of the second cycle. This result is also backed up by Lathufirdaush (2014) where she found that theme-based instruction was also able to increase the students' speaking ability in an elementary school in Bandung. Similar result is also found by Amiri and Fatemi (2014) where they found that CBI significantly increases the students' achievement compared to grammar translation method (GTM). Their findings also echoed several experts findings in which they agreed that content based instruction have some benefits like fostering academic growth while at the same time develop language proficiency and that the learners achieve more when emphasis is more on the meaningful and relevant content than the form of language being taugt (Crandal, 1993; Short, 1997; Snow, 1998; Stroller, 2004; Curtain 1995; Met, 1991, as cited in Amiri and Fatemi, 20145).

However, as the participants of this study have homogenous background as lecturers of education sciences and that the theme being chosen in this study are both about themes that are closer to them, it may have different result when the theme is something that are totally different from the ones that they are familiar with. In addition, since the instrument of the study is the Nelson Proficiency Test which are mostly pronouns, it may not be overly sufficient to show the advantage of using this content-based instruction compared to other approaches in language. Another instruments are needed in order to create a broader generalization on the advantage of using this Content-Based Instruction in accelerating the English mastery of non-English lecturers at IAIN Sultan Amai Gorontalo. In addition, it may also be interesting to see whether the non-education related theme will bring about similar results on the ability of this approach to accelerate the participants' English mastery.

Regardless, as the original purposes of this study is as the lesson learned. It can be sufficiently claimed that Content based-instruction can be used to accelerate the English mastery of non-English lecturers in this study by using the themes that are closer to these lecturers.

This present study implies that in order to increase the non-English lecturers' mastery of English using the theme-based instruction, the themes that are closer to the participants will be able to better accelerate their language mastery. However, this claim needs to be verified in a later study. This result also implies that as a lesson learned if we want to accelerate the language 


\section{Volume 5, Number 02, December 2019}

mastery of the non-English language students using this CBI syllabus or approach, using themes that are closer to the participants may be more beneficial in increasing their language mastery

\section{E. CONCLUSION}

This study has proven that content-based instruction, specifically the theme-based instruction can be used to increase the English mastery of the non-English lecturers at IAIN SAG. This finding by some extent can be used as a lesson learned for the massive English education for non-English students in Islamic University in order to internationalize the education at the Islamic universities in Indonesia.

\section{REFERENCES}

Amiri, Mostafa., Azhar Husaini, Fatemi. (2014). The impact of content-based instruction on students' achievement in ESP courses and their language learning orientation. The Theory and Practices on Language Studies. Vol. 4 (10). Pp 2157-2167, October 2014, Retrieved April 2015 from: https://profdoc.um.ac.ir/articles/a/1044240.pdf

Davies, S. (2003). Content based instruction in EFL contexts. The Internet TESL 31 Journal, 9(2), Retrieved April 25, 2018 from http://iteslj.org/Articles/ Davies-CBI.html

Duenas, Maria (2004). The whats, whys, hows and whos of the content-based instruction in second/foreign language education. International Journal of English Studies (IJES) col.4 (1). Pp 73-96. Retrieved April 25, 2018 from: https://dialnet.unirioja.es/descarga/articulo/919483.pdf

Lathufirdaush, Fitria. (2014). The implementation of theme-based teaching to improve students' speaking skill (a classroom action research at one of elementary schools in Bandung. Journal of English and Education 2014 Vol 2 (1) pp 9-16. Retrieved April 28, 2018 from https://media.neliti.com/media/publications/192521-EN-the-implementation-oftheme-based-teachi.pdf

Kessler, C. \& E. M. Quinn. (1987) SEL and Science Learning. ESL through content-area instruction: Mathematics, science, social studies SL and Science Learning. J. Crandall. Englewood Cliff, NJ, Prentice-Hall Regents.

Khasinah,Siti (2013). Classroom Action Research. Jurnal Pionir, Vol. 1 (1), July- December 2013. Retrieved April 29, 2018 from: https://jurnal.arraniry.ac.id/index.php/Pionir/article/download/159/140

Lee, Okhee., Helen Quinn., Guadalupe, Valdes (2013). Science and language for english language learners in relation to next generation science standards and with implications for common core state standards for english language arts and mathematics. Educational 
Reseracher 2013 Vol. 42 (223). Retrieved April 20, 2018 from: http://edr.sagepub.com/content/42/4/223

M. Brinton, Donna. (2012). Content-Based Instruction in English for Specific Purposes. Retrieved April 10, 2018 from: https://www.researchgate.net/publication/315713749_Content-

Based_Instruction_in_English_for_Specific_Purposes

Richards, J., \& Rodgers, T. (2001). Approaches and methods in language teaching. New York: Cambridge University Press

Saeidi, Manhaz., Elena Ibrahim Farshchi (2015). The effect of communication strategy teaching on EFL learners' oral production in content-based courses. Theory and Practice on Language Studies. Vol 5 (1) pp 71-78. January 20125. Retrieved April 10, 2018 from http://dx.doi.org/10.17507/tpls.0501.09

Stroller, F. (2002). Project Work: A means to promote language and content. In J. C. Richards \& W. A. Renandya (eds.), Methodology in Language teaching: An antohology of current practice. Cambridge: Cambridge University Press, 107-119. 


\section{APPENDICES}

\section{APPENDIX A. THE NELSON TEST OF ACHIEVEMENT (TEST 050 C)}

Directions: Choose the correct answer and mark your answer sheet. Only one answer is correct.

1. A) The bird are in the sky B) A bird's in a sky

C) The birds in a sky D) The bird's in the sky

2. What ........... doing?

A) are they B) do they C) does they D) is they

3. Jane and Tom .............. the door.

A) are walking at B) walk at $\mathrm{C}$ ) walks to $\mathrm{D}$ ) are walking to

4. Charles and I

A) am here B) we are here C) are here D) we here

5. Ann, what ..?

A) is doing B) she's doing C) are doing D) are you doing

6. Tom's street.

A) in the B) at the C) into the D) under

7. How many girls are there in the room?

A) There are any B) There's one C) A girl D) There two

8. Mary works, but

A) works Tom? B) does Tom? C) Tom does? D) Tom works?

9. Liz is looking at ...........

A) them B) they C) there D) their

10. Who's that girl?

A) He's Elizabeth B) Her name Sarah C) She's a good girl D) It's Anne

11. Where's the dog?

A) He's under chair B) There's on the table C) It's near the window D) Its here

12. Is John tall?

A) Yes, he's B) No, he'sn't C) No, his not D) Yes, he is

13. What's his name?

A) It John B) It's John C) John it's the name D) Its John

14. Do you draw or write?

A) I'm draw and write B) I drawing and writing

C) I'm not draw but I'm write D) I draw and I write

15. Is that a chair?

A) Yes, that's B) Yes, there is C) Yes, it is D) Yes, it's that chair 
16. Is this chair brown?

A) No, isn't brown chair B) No, this is the green chair

C) Yes, it's brown D) Yes, it is a brown

17. What's her father doing?

A) Her working in the garden B) Working in the garden

C) Is working in the garden D) She is working in the garden

18. How many books are there?

A) They're many B) There are many

C) There are eight D) Are two books there

19. A) Is that red book a big? B) Is that book a big red?

C) Is red that big book? D) Is that red book big?

20. Anne tomorrow.

A) can $\operatorname{sing}$ B) can to $\sin ($ C) is going sing D) going to sing

21. The pen is his pocket.

A) in B) into C) at D) to

22. The car is the tree.

A) near of B) with C) beside D) next

23. What's that man?

A) He's John B) Yes, it's a man C) It's John D) He's a teacher

24. Do you like the boat?

A) No, I don't like it B) Yes, I like him C) No, I like not D) Yes, I like

25. A) Ken is talking to Jane and we B) We and Jane is talking to Ken

C) Jane and we talking to Ken D) We are talking to Ken and Jane

26. A) Is you friend that pretty girl? B) Is that friend you're pretty girl?

C) Is that girl pretty your friend? D) Is that pretty girl your friend?

27. A) Is this your hat there? B) Are those your hat there?

C) Are those your hats there? D) Is this your hats here?

28. She is writing

A) on any book B) in a paper C) with a pen D) by pencil

29. A) Do Gary live in Bristol now? B) Does Gary live in Bristol now?

C) Is living in Bristol now, Gary? D) Does now Gary live in Bristol?

30. Monday is the first day.

A) Tuesday is the second B) The second is Thursday

C) Tuesday is the fourth D) The fourth is Thursday 
31. Mike is beside Pat. Pat is Mike.

A) behind $\mathrm{B}$ ) between $\mathrm{C}$ ) beside $\mathrm{D}$ ) in front of

32. Tom is Mrs Black's son
A) She is his daughter $\mathrm{B}$ )
B) He is his son $\mathrm{C}$ )
C) She is her son $\mathrm{D}$
) He is her son

33. A) Go over there to they B) Go over there to them

C) Come over there to me D) Come to them over here

34. A) Look my garden, Susan! B) Susan looks my garden.

C) Susan is look at my garden. D) Look at my garden, Susan!

35. A) You know not the old man B) You know a old man

C) An old man knows you D) An old man don't knows you

36. Watch

A) him and his $\operatorname{dog}$ B) he and he's $\operatorname{dog}$ C) him and he's $\operatorname{dog}$ D) him and its dog 37. Whose house is this? It's house.

A) the Mr Smith's B) our C) Mrs' Smith D) she's

38. A) Where are they going put the books? B) Where there are going to put the books?

C) Where are they going to put the books? D) Where are there going put the books?

39. A) Jack's English and Anne are two B) Jack's English and Anne is too English

C) Jack's English and Anne's, too D) Jack's English and Anne is, too

40. Do pigs fly?

A) No, dogs don't B) No, and not dogs, too

C) No, and dogs not D) No, and dog doesn't fly

41. Jack is standing beside

A) us B) its C) they D) your

42. This car is

A) of John B) to John C) John's D) Johns'

43. A) Betty has some flower B) Betty's has any flowers

C) Betty's any flowers D) Betty has some flowers

44. A) These are the third lesson B) This is the lesson two

C) This a lesson, too D) This is the third lesson

45. A) Tom cans have Joan's bicycle B) Tom can have Joan's bicycle

C) Tom can to have Joan's bicycle D) Tom can has Joan's bicycle

46. It's 11:30.

A) Yes, it's thirty past eleven B) Yes, it's half past eleven

C) Yes, its' thirty to twelve D) Yes, its half to twelve 
47. 439 is

A) four hundred and thirty nine B) four hundreds and thirty nine

C) four hundred thirty nine D) four hundreds thirty and nine

48. A) The teacher don't like some book B) The teacher doesn't likes some book

C) The teacher don't like his book D) The teacher doesn't like her book

49. Mother washes the girls' hair. Look, she

A) is washing it now B) washes it now $C$ ) is washing them now D) washes them now

50. The cat has

A) the long legs B) long legs C) the legs long D) legs long 